\title{
A TERRA INDÍGENA KRĨKATI, A MOROSIDADE DO ESTADO E A VIDA (IM) POSSIVEL DOS ÍNDIOS
}

\section{KRITKATI INDIGENOUS LAND, THE SLOWNESS OF THE STATE AND THE (IM) POSSIBLE LIFE OF THE INDIGENOUS PEOPLE}

\author{
Júlia Trujillo Miras* \\ Kátia Núbia Ferreira Corrêa**
}

Introdução

0 direito dos povos indígenas à terra é previsto pela Constituição Federal (CF) de 1988 que, no artigo 231, reconhece aos índios "sua organização social, costumes, línguas, crenças e tradições, e os direitos originários sobre as terras que tradicional- mente ocupam, competindo à União demarcá-las, proteger e fazer respeitar todos os seus bens". O Decreto $\mathrm{n}^{\circ} 1.775 / 96$ estabeleceu os procedimentos que o processo de regularização fundiária deve seguir para garantir que a Terra Indígena (TI) seja corretamente demarcada ${ }^{1}$. A Portaria 14, de 9 de janeiro de 1996, especificou, por sua

\footnotetext{
* Mestra em Antropologia Social pela Universidade de Brasília - UNB (Brasília/DF/BR).juliamiras@gmail. com

${ }^{* *}$ Doutora em Ciências Sociais pela Universidade Federal do Maranhão. É pesquisadora do Grupo de Pesquisa intitulado “Estado Multicultural e Políticas Públicas”. katianubiaf@bol.com.br

1. As etapas que devem ser seguidas para a regularização fundiária da TI, são as seguintes: (i) estudo de identificação e produção do Relatório Circunstanciado de Identificação e Delimitação (RCID) - coordenado por antropólogo e complementado por Grupo Técnico (GT); (ii) aprovação do relatório pela Funai e publicação de resumo no Diário Oficial da União; (iii) abertura de prazo de 90 dias para contestação por parte dos interessados e elaboração de pareceres no prazo de 60 dias, pela Funai, sobre as razões dos interessados; (iv) deliberação do Ministro da Justiça que deve, em 30 dias, determinar a expedição da portaria declaratória, ou prescrever diligências ou ainda desaprovar a identificação; (v) demarcação física da área e reassentamento dos eventuais ocupantes não-índios; (vi) homologação pelo Presidente da República; (vii) registro no SPU e cartório de imóveis da comarca correspondente.Cf. Decreto 1.775 de 8 de janeiro de 1996.
} 
vez, todos os elementos e dados que devem constar do Relatório Circunstanciado de Identifıcação e Delimitação (RCID), produto do primeiro procedimento a ser realizado para se instituir uma TI.

Em outubro de 2004 foi publicada a portaria de homologação da Terra Indígena Krĩkati² $^{2}$ Uma área de 144.675 mil hectares, no sul do estado do Maranhão, habitada, à época, por cerca de 600 Krĩkati (povo Timbira, falante de uma língua da família Jê) que viviam na aldeia São José. 0 longo processo de regularização fundiária dessa terra, que teve início em 1974, quando o chefe do Posto Indígena Krĩkati elaborou a primeira proposta de limites da área que previa para o povo uma área de 25.000 ha, parecia ter chegado ao fim. Entretanto, treze anos depois, a TI não se encontra totalmente desintrusada e ocupantes não-indígenas ainda vivem na região sul da área, conhecida como Arraia, por abrigar o rio de mesmo nome. Importante frisar aqui a permanente morosidade do Estado frente à não consolidação dos direitos indígenas, já reconhecidos por sua própria máquina burocrática, para que possamos refletir sobre o que este modo de agir produz na terra e nas vidas.

Em 11 de maio de 2017, Otávio Filho Krĩkati e Daniel Filho Krîkati pescavam em um açude próximo ao rio Arraia quando foram disparados, na direção deles, tiros de arma de fogo. "Por sorte, não foram atingidos”, dizia matéria publicada quatro dias depois do ataque 3 . No local onde está o açude, há uma fazenda. Há também um enorme buritizal e a região mais rica em recursos hídricos de toda a TI. 0 rio Arraia abriga também uma importante festa realizada todos os anos pelos Krîkati, que reúne todas as aldeias krĩkati, além de parentes de outros povos Timbira para participar da grande pescaria (embora o número de peixes esteja diminuindo a cada ano, como eles mesmos narram).

Importante fonte de recursos de subsistência, e local onde se realiza uma importante festa tradicional: estes já seriam motivos suficientes para garantir o usufruto exclusivo da área para o povo indígena, de acordo com o que determina a CF. Entretanto, ao escutar as palavras de Filomena ${ }^{4}$, uma das responsáveis pelo movimento de retomada e ocupação do Arraia pelos índios, outras relações surgem como fundamentais: "Eu que acabei de me criar lá no Arraia, pois eu vou lá morar lá, aonde que meu bisavô nasceu, se acabou de criar, pois eu vou morar lá. Ele gostava de andar comigo para lá desde quando eu era pequena. Foi eu quem primeiro quis vir para cá”. Mesmo quando os parentes Krĩkati falam sobre o risco de se viver tão próximo aos fazendeiros, ela não se abala em seu propósito e afirma que

2. A Terra Indígena Krĩkati situa-se no sudoeste do Maranhão entre os municípios de Montes Altos (oeste), Amarante (norte), Lajeado Novo (sul) e Sítio Novo (leste).

3. Disponivel em: $<$ http://www.cimi.org.br/site/pt-br/?system=newstaction=readttid=9276 $>$. Acesso em: 16 maio 2017.

4. Filomena e seus irmãos são considerados na aldeia São José e se consideram como aqueles que descendem da família que permaneceu na Aldeia Grande quando da dispersão dos povos Timbira dessa aldeia. Por tal, se reconhecem e são reconhecidos como os "Krîkati legítimos" ou Crẽhcatehcatiji: "os da aldeia grande". 0 elemento marcador dessa legitimidade é o fato de a família identificar a região do Arraia como o lugar aonde estão enterrados seus ancestrais, pois foi ali que seus ancestrais foram morar ao sair da Aldeia Grande (CORRÊA, 2016, p. 49-54). 
se [fazendeiro] quiser me matar, me mata, eu não vou virar pedra para viver todo o tempo não; daqui mais tarde eu vou ficar debaixo do chão; eu nasci para morrer, como é que eu vou sair? Com medo de quê? (Filomena Krĩkati, aldeia Arraia, julho de 2014.5).

A fala de Dona Filomena aponta para a importância vital da relação dela e de seus familiares com os lugares do passado, mas revela também que tais relações não são as mesmas para todos que se reconhecem (e são reconhecidos) como Krĩkati. Ela também aponta para a relação constitutiva entre vida e terra, ao se dispor a arriscar a vida na luta pela terra, pois viver só é possível ali, naquela terra específica ${ }^{6}$.

Neste artigo, nos propomos a perseguir alguns fios a partir da fala de Dona Filomena, nos atentando para o que acontece com a vida e a terra quando uma Terra Indígena é demarcada - e quando a efetividade desse ato do Estado não se consolida e coloca em risco a vida (d)na terra. Quando falamos aqui sobre a vida e a terra, é para chamar atenção para os efeitos que o processo de regularização fundiária de uma TI produz: não apenas nos papéis que passam de mesa em mesa, percorrendo burocracias estatais e produzindo novos papéis; também para os efeitos na terra, que passa a ser "propriedade da União" e a ter limites traçados como se fossem muros; e ainda na vida dos que nela habitam, que passarão a acionar ou- tras relações com os lugares, com o Estado e com as pessoas. 0 processo de regularização fundiária acontece pela ação de papéis e pela ação na terra - ambos os movimentos fazem o processo caminhar. Ao mesmo tempo, como veremos no decorrer do texto, o processo de demarcação gera efeitos sobre a vida na terra. Se a construção de pessoas se faz junto com a construção de lugares, se ambos se constituem no ato de habitar (MIRAS, 2015), as transformações que a demarcação gera implicarão em novas configurações de grupos, parentes e lugares na terra.

A ideia de lugar aqui utilizada se funda naquela elaborada por Casey (1996), na qual o conceito de lugar pode ser entendido como um emaranhado de relações entre humanos e não-humanos que produzem cotidianamente trajetórias no espaço (MIRAS, 2015). 0 lugar é, portanto, constituído no espaço por meio dos acontecimentos e ações dos viventes que o habitam. Como explica Casey (1996, p. 24): "the livingmoving body is essential to the process of emplacement: lived bodies belong to places and help to constitute them".

Comecemos, por hora, nos aproximando do processo de regularização fundiária da TI, seu percurso e seus percalços, para que possamos, a partir dele, nos aproximar dos modos krîkati de viver na terra e observar o modo de agir do Estado brasileiro quando se trata da efetivação dos direitos

5. As falas dos Krîkati foram feitas para a pesquisadora Katia Núbia F. Corrêa, ao longo do trabalho de campo realizado no contexto de sua pesquisa de doutoramento.

6. 0 paralelo com a Carta da Comunidade Guarani-Kaiowá de PyelitoKue/Mbarakay-Iguatemi-MS para o Governo e Justiça do Brasil publicada em 2012, não pode ser ignorado. Ali, como elaborou Luísa Molina (2017, p.19), os índios também afırmavam "o seu propósito inequívoco de não sair - nem vivos, nem mortos - das margens do rio Hovy, sua terra, onde estão enterrados os seus antepassados”. Para nos aproximarmos dos sentidos implicados nessas falas é preciso, como propõe Molina, que coloquemos em perspectiva os sentidos contidos nas palavras vida e morte: viver qualquer vida, em qualquer terra é ainda viver? 
territoriais indígenas. Molina (2017, p.44) ao tratar sobre esse modo de agir do Estado brasileiro, chama atenção para o fato de que, apesar da "constante formulação normativa sobre o que as categorias de terra ou área indígena deveriam abranger, e como a sua materialização deve se dar”, o exercício de "fazer valer" esses direitos se perde nas idas e vindas dos papéis e dos interesses, o que resulta na não consolidação de tais direitos. Esse modus operandi é denominado pela autora como "faz de conta", uma operação que permite ao Estado fazer de conta, por exemplo, que vidas não correm risco e deixar de agir (sobre a terra) quando indígenas sofrem um atentado.

\section{0 processo de regularização fundiária: história sem fim}

Atualmente, os Krĩkati são uma população de mais de mil e cem pessoas ${ }^{8}$, espalhados em seis aldeias ${ }^{9}$. 0 rápido aumento populacional e de aldeias após a demarcação da TI foi previsto na perícia antropológica escrita por Maria Elisa Ladeira (1989), no âmbito da ação 1875/81, que resultou na homologação da Terra Indígena em 2004.

Ao longo dos 30 anos que separaram o início e o (suposto) fim do processo demar- catório, verificou-se importante mudança de paradigma do Estado brasileiro. De uma visão predominantemente assimilacionista $^{10}$ passou-se, após a Constituinte de 1988, a reconhecer aos índios o direito de viver segundo seus "usos, costumes e tradições" (Constituição Federal, art. 231). Isso implica que a Terra Indígena a ser demarcada não deveria se fundamentar na escolha de áreas que permitissem apenas a subsistência desses povos no presente, mas sim permitir a sua reprodução enquanto grupo também no futuro. Para tanto, não basta garantir a terra apenas no que diz respeito ao acesso a recursos naturais, mas também em termos culturais, conceitos indissociáveis (ou, ao menos, sobrepostos em diversos sentidos) para os povos indigenas.

É importante perceber, contudo, que embora o Estado garanta aos indígenas o usufruto exclusivo sobre as terras que tradicionalmente ocupam (Constituição Federal, art. 231 §2) e, desse modo, reconheça a existência desses outros "modos de habitar”, a categoria Terra Indígena é exógena aos povos nativos. É um conceito jurídico administrativo construído pelo Estado para dar conta desses outros modos, trazendo-os para dentro de seu ordenamento jurídico. Para os diversos povos indígenas, terra

7. Agradecemos a Luísa Molina pelos comentários feitos sobre os usos do termo "faz de conta" e suas implicações, e também pelas demais sugestões dadas ao texto.

8. FUNASA (2014)

9. São elas: São José, Raiz, Campo Alegre, Jerusalém, Arraia e Recanto dos Cocais.

10. Aqui não podemos deixar de mencionar o nome do primeiro órgão indigenista que, não por acaso, juntava o Serviço de Proteção aos Índios com a Localização de Trabalhadores Nacionais, - o SPILTN, criado em 1910 -, isto é, organizava essas duas ações como dois passos de um processo, qual seja, aquele de assimilação dos indígenas à sociedade brasileira enquanto “trabalhadores nacionais". Souza Lima (1995) afırma que esta visão sobre os índios (e seus futuros) teve consequências sobre o formato e tamanho das terras demarcadas naquele período, que a defınição das áreas a serem reservadas considerava apenas o espaço necessário à subsistência daquelas pessoas no presente, como se seu futuro enquanto indígenas não fosse possivel ou desejável. 
não se resume a um território demarcado em mapa, ela é multiplicidade. Como vemos, é preciso estar atento para os múltiplos significados que a palavra terra aciona. Utilizaremos doravante a grafia T/terra, como formulada por Coelho de Souza et al. (2016, p. 30, nota 7), como um "lembrete da 'polissemia' do termo [...] para sinalizar tanto os significados nela contidos quanto aqueles incontidos, obrigando ao seu transbordamento: Planeta/solo, Globo/superfície, Concebido/vivido, Continente/conteúdo, Ego/oikos, cosmologia/economia, etc".

A TI, enquanto uma categoria de ordenamento territorial criada pelo Estado brasileiro, surge para atender, primeiramente, suas necessidades de ordenação e dominação da terra. Se hoje a demanda por demarcação surge pelas vozes indígenas, é porque esse modelo (o de demarcar uma área com limites fixos) é o modelo possível, a única ordem possivel ${ }^{11}$ para o reconhecimento do direito desses povos à terra. Este fato, contudo, não deve nos impedir de notar que cada povo possui territorialidades próprias constituídas em relação com a T/terra e cotidianamente atualizadas. Deste modo, cada processo demarcatório sofre transformações e é atualizado pelas ações do povo indígena nos papéis e na T/terra. Portanto, embora atualizada como TI, a T/terra continuará a ser vivida pelos indígenas a seu próprio modo.

Maria Elisa Ladeira (1989, p.5), na perícia citada, relembra que a Constituição garante o direito dos índios à posse e ao usufruto de seu território independentemente da demarcação. Reafırma, contudo, a ne- cessidade do ato administrativo devido aos modos diversos e incompatíveis como índios e regionais se relacionam com a T/terra. Da perspectiva da população regional, a terra onde os marcos de apropriação, uso ou dominação pelo homem não são evidentes, é terra vazia (LADEIRA, 1989, p.7) e, portanto, um solo à espera de ser tomado. Os modos indígenas de ocupação não se fazem vistos pelos mesmos marcos (cerca, pasto, monocultura), por isso a importância da regularização fundiária da TI: modo que torna visivel a "ocupação" da terra para os não-indígenas, assim protegendo o direito indígena à terra. Bernardino Krĩkati aponta para os efeitos desse processo de fixação de limites, assim como para a exterioridade desse modelo de demarcar a terra:

0 limite foi feito; quando o índio sai para caçar só tem capoeira; vai andando, vai andando e chega no limite; os animais que estão dentro do limite sai e vai procurar mata [porque a terra deles, os não índios deixaram só a capoeira] e os índios vão atrás; as caças vão procurar áreas de mata virgem; caça não pensa; vai procurar o melhor lugar para se proteger; aí os brancos não deixam os índios caçar fora dos limites; por outro lado, caça também vem entrando de lá [do lugar dos não índios] para cá; branco vem atrás e entra na área; assim continua o processo de invasão de nossa terra apesar de demarcada. (Bernardino, aldeia Campo Alegre, 9 out. 2014).

Criar limites e cercar o solo é o modo como o Estado se relaciona com a terra, produzindo territórios, tanto administrati-

11. Categoria utilizada por Lander (2005, p.22) para fazer referência ao conhecimento científico moderno que naturaliza as relações sociais e toma a sociedade liberal, não apenas como a ordem social desejável, mas como a única possível. 
vos como produtivos. Para os índios, esse tipo de ocupação interrompe seus modos de habitar e impõe um modelo novo de conhecer e de se relacionar com a T/terra. Em outras palavras, um outro modelo de organização espacial que inscreve relações em fronteiras traçadas na terra e não mais nos corpos (e seus fluxos) ${ }^{12}$.

As propostas de traçado para a Terra Indígena Krĩkati se transformaram ao longo da duração do processo, não apenas pelo esforço da Fundação Nacional do Índio (FUNAI) em adequar a proposta de área e considerar as novas normativas, inclusive a nova Constituição, mas principalmente pela resistência dos Krĩkati, que não cessaram de lutar pela garantia do seu direito de viver na terra - não uma terra qualquer, mas aquela "tradicionalmente ocupada", aquela que se faz indissociável de suas vidas. Para tanto, tiveram que enfrentar, como veremos a seguir, além das idas e vindas da burocracia do órgão indigenista (movimentos que, conforme revelam as narrativas indígenas e os documentos do processo, são muitas vezes motivados por interesses políticos regionais que agem sobre seus rumos), mas um processo judicial. 0 processo de demarcação Krĩkati teve início em 1974, três anos após a instalação do Posto de Assistência da Funai na aldeia São José, onde os Krĩkati ficaram forçosamente concentrados por quase trinta anos, como resultado da invasão de seu território tradicional. A primeira proposta de limites foi elaborada pelo chefe do posto indígena Krĩkati, Antonio Marmor Sant'ana, da 6a Delegacia Regional (proc. 0867/92, p.
558) e apresentou uma área de 25.000 ha. No ano seguinte, uma nova proposta foi elaborada pelo engenheiro agrônomo José Roberto Soares, que apresentou uma área de 42.000 ha. Ainda em 1975, o agente do Posto Indígena mostrou aos Krĩkati um mapa contendo a proposta de demarcação. Ao terem acesso ao mapa do que poderia ser sua futura Terra Indígena, os Krĩkati solicitaram a ajuda de Dolores Newton, antropóloga que pesquisava junto a eles havia doze anos, para escrever uma carta ao presidente da Funai em Brasília, onde falaram sobre seu modo de habitar a terra e a impossibilidade de fazê-lo em uma área como a desenhada no mapa apresentado pelo Agente de Posto (proc. 224/80, p. 132):

A largura da terra demarcada no mapa, o po-
vo não aceita, nem eu, o chefe Francisco. Eu
sempre teria medo de que o povo daqui pas-
sa lá fora. Eles têm costume de andar três até
cinco léguas (6 quilômetros numa légua) pa-
ra fora da aldeia, costume que é do muito
tempo no passado não só agora. Então pre-
cisa terra para passar assim, para não criar
problemas.

Francisco $\mathrm{Krinkati}^{13}$ nos fala sobre o modo de habitar dos Krîkati, um habitar fundado no ato de constituir centros e "passar para fora”, um território feito pelo ato contínuo de deslocamento e retorno, trajetórias constituídas por relações com todos os seres que habitam a $\mathrm{T} /$ terra e com ela mesma. Fala também que, frente ao modo não-indígena de ocupar a terra, era preciso garantir uma terra na qual aquilo que ele

12. Cf. Deleuze\&tGuatarri, 1972.

13. Foi o primeiro chefe/cacique da aldeia São José no período de concentração do povo na referida aldeia. Ficou nessa função por 21 anos. 
denomina "lá fora" (por não se constituir como o espaço domesticado da aldeia ou da roça, por exemplo) ficasse dentro da Terra Indígena, para evitar "criar problemas" com os não-indígenas. 0 "lá fora” não podia ser propriedade de um outro exclusivo ${ }^{14}$, pois se assim o fosse, seria um espaço impedido ao passar do povo Krĩkati. Ao compreender a diferença entre o modo indígena e nãoindígena de habitar, o líder descreveu os lugares que a TI deveria abarcar e apresentou a toponimia, as narrativas e as experiências vividas com o lugar, como podemos ler a seguir (proc. 224/80, p.106):

Esta área, ou pelo menos uma metade do cocal, os Krĩkati utilizam durante os meses de agosto e setembro. Aqui estamos acostumados a andar para buscar côco e faz tinguijada. Este território entre os Rios Arraia e Lageado pertence aos Krĩkati. Temos várias pessoas que nasceram mesmas em aldeias desta região; nomes de três destas aldeias são komchíkuh, piphúhpo e ronkú. Só por causa do cocal precisamos tanto do território intermediário da aldeia até lá. Com garantia de liberdade de passar através da área no sul até o cocal não precisaria tanta área no sul. Mas, o povo tem medo que os civilizados não deixem os Krĩkati entrar se estes lugares ficam por fora da área demarcada.

Francisco percebe que para poderem viver (sem medo) seria preciso marcar os lugares como de uso exclusivo aos indígenas, como afirmou ao final da carta:
"Em resumo, o povo Krĩkati necessita um lugar mais folgado para evitar problemas com vizinhos" (proc. 224/80, p.106). A carta descreveu um território constituído por lugares e não por limites, por trajetórias que compõem uma memória coletiva e formam uma rede de lugares identificados pelas toponímias e narrativas que podem ser transformadas, a posteriori, em mapas daquele habitat. Lugares que são atualizados nas narrativas e também no ato contínuo de caminhar por eles, como podemos ler nos trechos abaixo (proc. 224/80. p.105):

No Riacho Batalha tem um lugar conhecido regionalmente pelo nome Baixão e que está a umas duas léguas e quatro kms. Ao leste da aldeia. Aqui está um posto com lugar de peixe que no passado era sempre uma "arrancheira" (arranchamento) e "campo" do povo Krîkati. Inclusive o nome Batalha indicou as antigas batalhas que os bisavós do presente Krîkati tinham com civilizados entrando neste lugar.

Ao finalizar a carta, na qual todos os limites apontados pelo mapa foram revisitados pelas palavras de Francisco, Dolores Newton produziu um pequeno relatório sobre o uso da terra pelos Krĩkati. No intuito de contribuir para com os objetivos da carta, expôs algumas informações sobre a localização e as práticas produtivas do povo. Afırmou, primeiro, que "hoje o tamanho da tribo está muito diminuído, mas a área que eles estão pedindo para a

14. Para o não-indigena a relação com a terra é fundada em uma ordenação do solo baseada no modelo da propriedade e, portanto, em uma relação em que o meu direito sobre a terra se define contra o (não) direto dos outros. A propriedade é poder de exclusividade e exclusão sobre um certo solo. É desse modo que os não indígenas se territorializam, sempre contra outros. Dessa perspectiva, não é possível, conceber uma terra sem proprietário (MIRAS, 2015). 
demarcação é apenas uma pequena parte só do antigo território" (proc. 224/80, p. 107). Newton finalizou seu relatório falando sobre a impossibilidade de construção de diálogos compartilhados sobre a terra, entre regionais e Krîkati, como podemos ler (proc. 224/80.p. 108):

Durante julho de 1975, os Agentes do Posto Krĩkati marcaram reuniões com os líderes dos Krĩkati e moradores vizinhos dos Krĩkati com quem os Krîkati estão tendo dificuldades. Estes moradores não mostraram nenhum desejo de fazer compromisso para deixar os Krĩkati buscarem coleta nas terras tradicionais que os moradores estavam em processo de cercar. Parece que a situação não tem uma solução informal.

Frente à demanda dos Krĩkati, a Funai constituiu um Grupo Trabalho (GT) por meio do convênio Funai/Radam ${ }^{15}$ que definiu, em 1976, uma área de 62.350 ha. 0 limite proposto pela Funai desconsiderou por completo as reivindicações dos Krĩkati postas em carta e levadas ao presidente da Funai pela antropóloga Dolores Newton. Ao desconsiderar as demandas dos índios, o Estado operou duplamente por "faz de conta", pois primeiro "fez de conta" que os documentos e as palavras escritas em defesa da terra não existem e, posteriormente, "fez de conta" que o direito territorial indígena estava sendo respeitado ao constituir um novo GT. Contudo, como veremos, o faz de conta do Estado não consegue produzir como efeito o apagamento dos índios ou de suas relações com a T/terra e, portanto, de suas demandas. No entanto, um de seus efeitos é a morosidade no processo de regularização da TI Krĩkati que, por sua vez, ameaça cotidianamente a vida na terra.

A proposta da Funai de 62.350 ha não foi aceita pelos Krîkati, e tampouco pelos fazendeiros. Estes enviaram, em 1976, documentação aos gabinetes do então ministro do Interior e do presidente da Funai sugerindo alternativas à demarcação da terra Krĩkati. Argumentavam que fosse estudada a possibilidade de transferir os índios para o município de Amarante ${ }^{16}$ ou, quando muito, estabelecer uma área indígena de no máximo 20.000 ha. Solicitavam ainda que não se demarcasse uma terra específıca para os Krĩkati com o propósito de não alterar o modus vivendi da "sociedade pacata e ordeira de Montes Altos” e, assim, manter os Krĩkati em "harmoniosa convivência com os habitantes da região tal como sempre aconteceu ao longo de cerca de dois séculos”. Os fazendeiros também agiam por faz de conta, ao ignorar o extermínio de vidas Krĩkati levado a cabo nesse período. Após a proposta de demarcação ser publicada no DOU, os mesmos enviaram um abaixo-assinado ${ }^{17}$, onde afirmavam concordar que se demarcasse uma área para os índios, contanto que esta estivesse em acordo com aquela "realmente ocupada" por eles.

15. 0 Projeto RADAM (Radar na Amazônia) foi criado em 1970 com o objetivo de coletar dados sobre os aspectos físicos e bióticos do território brasileiro, por meio de um aerolevantamento.

16. Alegavam os fazendeiros que a demarcação da terra Krĩkati "pelo dilatadíssimo tamanho", compreenderia as melhores terras do municipio de Montes Altos e redundaria no "assenhoramento" de suas propriedades (AÇÃO DEMARCATÓRIA, 1980, p.4-5).

17. "Dos Moradores e Proprietários de Terras circunvizinhas da aldeia indígena de São José, da tribo Krĩkati, localizada no Município de Montes Altos, Estado do Maranhão” (proc. 532/78, p.4). 
Em 1979, a Funai determinou a realização de novo Grupo de Trabalho, uma vez que os relatórios produzidos até então não se adequavam às normas que regulavam o processo de demarcação na época ${ }^{18}$. A antropóloga Delvair Melatti coordenou esse GT, que identificou uma área de 136.600 ha. Descontentes com o limite proposto no relatório de Melatti, os fazendeiros entraram com uma ação ${ }^{19}$ na Justiça, em 1981, solicitando uma demarcação judicial com base na apresentação de títulos de propriedade da terra. Devido ao clima de hostilidade presente na região, o juiz responsável mandou suspender a demarcação administrativa da TI Krĩkati, o que foi considerado uma vitória pelos fazendeiros que passaram a agir de modo mais agressivo para garantir a propriedade da terra.

Com a suspensão da demarcação administrativa, a Funai, com o intuito de prosseguir com o processo de regularização fundiária, pressionou os Krĩkati para que aceitassem reduzir o tamanho de seu território. Assustados com a postura incisiva da Funai e com a ameaça de não terem nenhuma terra demarcada, os índios cederam à pressão do órgão e aceitaram a criação de um terceiro GT para a redução da área, ainda em 1981. 0 novo perímetro proposto reduzia a área de 136.000 ha para 85.500 ha, excluindo de seus limites o povoado Quiosque ${ }^{20}$ e a região do rio Arraia ${ }^{21}$.

A configuração desse novo limite implicava não apenas a exclusão de lugares considerados fundamentais pelos índios, como a permanência de não índios em uma área muito próxima da aldeia São José, o que representava grande risco à vida, na visão krĩkati. Não era a primeira vez que esses dois lugares eram excluídos da proposta de

18. Decreto $n^{\circ} 76.999$ de 08/01/1976 e Portaria $n^{\circ}$ 527/N de 03/08/1978 (proc. 224/80, p.85).

19. Ação de Demarcação que Leon DelixMilhomen e outros movem contra a Fundação

Nacional do Índio", de n¹875/81.

20. Wilma Leitão, antropóloga da Funai,que atuou como assistente técnica da perícia judicial da TI Krĩkati, afırma a importância de incluir a área do povoado de Quiosque na demarcação: "considerando-se que a expansão do referido povoado tende a se fazer através da invasão das terras tradicionais dos índios, tal fato ameaça particularmente os poucos trechos de mata contínua existente dentro da área indígena. É importante notar que é somente neste local que os índios encontram pau-roxo, utilizado na confecção de arcos, bordunas, pontas de flechas, além de entrar como elemento na confecção de chocalhos. Este local representa importante ponto de caça, além de abrigar a cabeceira tradicional do rio Pindaré (LEITÃo, 1989, p.6).

21. Sobre a inclusão do rio Arraias, Leitão aponta para importância da região em termos de recursos naturais e culturais, como podemos ler, a seguir: "É muito importante precisar as referências nesta região do rio Arraias, pois trata-se de um dos locais essenciais reivindicados pelos índios. Esta região foi, na entrada do século, importante ponto de aldeamento dos Krîkati e até o momento é muito utilizada. No que se refere a aspectos econômicos, este ponto é tradicional para arranchamentos, pois os índios praticam ali a caça, a pesca, coleta de babaçu e de matérias-primas para a confecção de seus utensílios e adornos, como por exemplo o importante Imbé (fibras pretas utilizadas em cestarias, arcos e flechas). Salientamos que a caça e pesca são muitas vezes atividades conjuntas, objeto de arranchamentos que podem incluir coleta. Enquanto local sagrado, esta área é utilizada para a realização de rituais importantes para o grupo. Anualmente os Krĩkati reúnem-se no rio Arraias para a realização da “tinguizada”. Nesta área é praticada também corrida de toras, sobretudo nas festas das mulheres. Tais eventos exprimem suas características indígenas e representam momentos de reafirmação de seus valores e de reprodução da sua cultura, garantindo-lhes a preservação de sua identidade étnica (LEITÃo, 1989, p.7-8; grifo nosso). 
delimitação da terra Krĩkati' ${ }^{22}$. A mesma recusa dos índios iria se dar sobre essa nova proposta, o que levou a uma nova paralisação do fluxo de demarcação da TI dentro do órgão indigenista.

No início de 1983, a área krĩkati foi incluída no projeto de compensação socioeconômica para as populações indígenas localizadas na região de influência do projeto Ferro-Carajás da Companhia Vale do Rio Doce (CVRD) ${ }^{23}$. As ações do projeto tinham como foco as áreas de saúde, educação e demarcação territorial. Por meio desse projeto, a CVRD passou a pressionar a máquina estatal para agir em prol da execução da regularização fundiária da TI Krĩkati. Nesse contexto, a Funai elaborou um cronograma para demarcar as reservas indígenas afetadas pelo projeto Ferro-Carajás e apresentou o prazo de agosto de 1983 para iniciar a demarcação física da terra krĩkati (CVRD à ABA, 1983, p.4;11. Tal ação, contudo, não ocorreu uma vez que o processo administrativo estava paralisado, aguardando o encaminhamento da ação judicial.

0 juiz encarregado do processo judicial havia autorizado, no ano de 1982, a demarcação das propriedades pertencentes aos autores da ação, contanto que "respeitadas as áreas ocupadas pelos silvícolas, incluídas entre os bens da União" (proc. 867/92, p. 796). Diversas tentativas de entrada na área Krĩkati para realizar a demarcação judicial foram impedidas pelos indígenas que exi- giam a presença da Funai para acompanhar as ações. Por fim, no ano de 1984, a Funai foi obrigada pela Justiça a acompanhar os agrimensores em sua tarefa. 0 resultado foi um laudo que confirmava a validade dos títulos dos não índios e apresentava, como uma imagem em negativo da área demarcada dos proprietários, uma terra de 13.125 ha para os índios.

Nesse mesmo ano, a regularização das áreas sob afetação do projeto Ferro-Carajás foi considerada a prioridade número 1 do convenio Funai/CVRD. Com o objetivo de garantir a continuidade da demarcação da TI Krĩkati, o projeto pagou os honorários da advogada da Funai, Maria Eunice Paiva, para estudar o processo judicial e propor encaminhamentos. Em nome do órgão, a advogada apresentou sua discordância com os termos da perícia judicial realizada pelos agrimensores e solicitou que o laudo da mesma fosse impugnado, requerendo ao juiz a realização de uma perícia antropológica. 0 juiz aceitou o pedido da Funai e determinou que também fosse realizada uma perícia sobre os títulos apresentados pelos autores, assim como o levantamento dos principais pontos cartográficos de delimitação da área.

Em 1989, com vistas a dar um parecer defınitivo sobre a situação da área em litígio, a Associação Brasileira de Antropologia (ABA) foi acionada para definir uma pessoa para produzir perícia antropológica

22. 0 GT Funai/Radam de 1977 também havia deixado de fora essas duas regiões, fato que gerou a recusa da proposta pelos Krĩkati e a pressão pela realização de novos estudos (que veio a ser o GT de Melatti). 23. Conforme documento disponível na Biblioteca Digital do Centro de Trabalho Indigenista, o convênio no valor de U\$ 13.596.000,00 firmado entre a Companhia Vale do Rio Doce e a Funai teve início em 1982 com duração de 5 anos e com o objetivo de beneficiar 23 áreas indígenas e, aproximadamente, 12 mil pessoas (BOTELHO, 1985, p. 2). Uma equipe de antropólogos indicados pela Associação Brasileira de Antropologia foi contratada pela CVDR para assessorar a empresa no acompanhamento e avaliação do projeto. 
dos limites da TI Krĩkati. A antropóloga Maria Elisa Ladeira foi contratada, com os recursos do convênio CVRD/Funai, para produzir a perícia que se constituiu como o primeiro estudo de identificação da terra produzido no marco da Constituição Federal de $1988^{24}$. 0 argumento principal apresentado pela antropóloga partiu da compreensão de que o "modo de produção" citado pela Constituição deveria ser compreendido para além da questão da subsistência, considerando igualmente questões socioculturais como o faccionalismo interno e as constantes fusões e cisões de aldeias, isto é, dizia a autora: "[a] trajetória histórica da ocupação territorial” do grupo (LADEIRA, 1989, p. 20-21). É preciso, afırmava a antropóloga em seu laudo pericial, imaginar a "reprodução" como englobando a forma de organização social desses povos que "carrega em si uma concepção de espaço e que exige para atualizar-se um espaço próprio, dominado, apropriado por esta forma” (p. 20-21). Caso contrário, segundo o argumento, as terras demarcadas não permitiriam aos grupos se reproduzirem enquanto coletivos autônomos, mas apenas que esses, pouco a pouco, se integrassem à sociedade nacional.

Após levar em conta todos os pressupostos antropológicos e legais para a identifıcação de uma Terra Indígena, Ladeira apresentou uma proposta de delimitação de 142.326 ha para a TI Krĩkati. 0 juiz federal encarregado do processo reconheceu a legitimidade da posse indígena sobre a área levantada pela perícia antropológica e, em 1991, julgou extinta a ação judicial movida pelos fazendeiros, considerando inválidos os 120 títulos de propriedade incidentes sobre a TI. A Funai encaminhou proposta de limite da Terra Indígena Krĩkati ao Ministério da Justiça, que ficou com superfície de 146.000 ha ${ }^{25}$. Em 1992, foi expedida a Portaria Declaratória $n^{\circ} 328$, que reconheceu a posse permanente indígena e determinou a demarcação da área em 45 dias após a data da expedição.

\section{Dos papéis à terra: a vida na demarcação}

A Terra Indígena Krĩkati estava mais próxima de ser consolidada, agora na própria terra, e não apenas nos papéis. Os trabalhos demarcatórios, contudo, não tiveram início no período determinado pela Portaria Declaratória, em decorrência do resultado da Apelação Cível de nº 92.01.067550 - movida pelos fazendeiros -, que sustentava, mais uma vez, a tese de que estes tinham a propriedade das terras reivindicadas pelos Krĩkati. A sentença favorável aos fazendeiros tornava nula a sentença da Justiça Federal de 1991, a qual tinha sido extinta sem julgamento do mérito e que garantia aos Krĩkati a posse permanente das terras.

0 ano de 1993 se constituiu como o prazo limite dado pela Constituição Federal de

24. 0 Art.231, § $1^{\circ}$ afirma que são terras tradicionalmente ocupadas pelos índios as por eles habitadas em caráter permanente, as utilizadas para suas atividades produtivas, as imprescindiveis à preservação dos recursos ambientais necessários a seu bem-estar e as necessárias à sua reprodução física e cultural, segundo seus usos, costumes e tradições.

25. A proposta de limites encaminhada pela Funai era de 142.326 ha, mas após alterações de limites feita pela Comissão Especial de Análise,criada no âmbito da Funai em 1991 com o objetivo de agilizar os processos para a demarcação das Terras Indígenas, a TI Krĩkati ficou com superfície de 146.000ha. 
1988 para a demarcação de todas as Terras Indígenas no Brasil e, no entanto, os Krĩkati ainda aguardavam o fim do processo de regularização de sua TI. Frente à morosidade da Funai, sempre presa às idas e vindas de papéis promovidas pela própria máquina estatal, em março daquele ano, os Krĩkati ameaçaram desligar as torres de transmissão de energia elétrica da Eletronorte que cruzam sua terra ${ }^{26}$, caso a demarcação não fosse realizada.

Ainda em 1993, o órgão indigenista recorreu ao Supremo Tribunal Federal solicitando um embargo de declaração da sentença favorável dada aos fazendeiros (Apelação Cível de $n^{\circ}$ 92.01.067550). Antes do resultado da sentença, a Funai promoveu uma concorrência pública para contratar firma especializada para realização da demarcação da terra Krĩkati nos limites de 146.000 ha, como determinava a Portaria Declaratória de $1992^{27}$.

Os trabalhos demarcatórios da firma contratada tiveram início em dezembro de 1994. Os fazendeiros, com a finalidade de impedir a demarcação, arregimentaram forças junto a políticos e lavradores de
Montes Altos e bloquearam a MA-280 28 , ateando fogo em pontes que ligavam o centro do município à aldeia São José e fazendo reféns o superintendente da Polícia Federal, o motorista da Funai e a enfermeira da Fundação Nacional de Saúde (FUNASA). Segundo relato de Marli Belizário ${ }^{29}$, os Krĩkati ficaram impedidos de entrar em Montes Altos para fazer compras e o cacique da aldeia, João Piauí, foi ameaçado de morte caso se aproximasse do povoado. Os fazendeiros exigiam que os policiais que prestavam apoio ao processo demarcatório se retirassem da TI. Como nos lembra Coe$\operatorname{lho}^{30}$ (2002, p.274), em seu estudo sobre a dinâmica da disputa pela terra entre índios e não índios no Maranhão, as estratégias judiciais utilizadas pelos vários atores ao longo da disputa, não excluem outras estratégias de luta "não regulamentadas".

Em 1995, o clima conflituoso entre índios e não índios se agravou devido ao assassinato de Manoel Mendes, índio Tentehar/Guajaja$\mathrm{ra}^{31}$. A principal suspeita é a de que posseiros sejam os responsáveis pela morte ocorrida dentro do território Krĩkati. Dois anos mais tarde, em 1997, lideranças Krĩkati ${ }^{32}$ foram

26. As torres da Eletronorte estendem-se por $35 \mathrm{~km}$ do território Krĩkati.

27. Ë possível imaginar que após o contexto do convênio com a CVRD, houve uma mudança na postura do órgão indigenista que passou a agir em prol da demarcação dos 146.000ha, identificados pela perícia e sustentado pelos índios, e não mais a questioná-los (afınal, o que estava em jogo era mais sua capacidade de demarcar os limites, do que estes em si).

28. Estrada que liga o município de Montes Altos à Terra Indígena Krĩkati, a MA-280 atravessa a TI Krĩkati ao meio.

29. Marli Belizário, casada com um Krĩkati e moradora a aldeia São José, é do povo Gavião - povo Timbira habitante da TI Governador, localizada também no sul do Maranhão e bastante próxima da TI Krĩkati -, tanto no sentido físico como cultural e social.

30. Essa dinâmica de disputa pela terra foi analisada no contexto da luta dos índios Tentehar/Guajajara de retirar de dentro de sua terra demarcada, a TI Cana Brava/Guajajara, dois grandes povoados: Alto Alegre e São Pedro dos Cacetes.

31. Manoel Mendes Tentehar/Guajajara ou Manoel Jacu, como era conhecido pelos Krîkati, participou ativamente na luta pela demarcação da TI Krĩkati. Vivia em aldeia guajajara localizada na mesma TI. 
impedidas de se deslocarem pela estrada MA280. Para chegar à aldeia, tiveram que andar toda a noite por dentro da mata. Este incidente e o fato de a demarcação não se realizar, foram os marcos finais para a decisão tomada em seguida no pátio da aldeia: derrubar as torres da Eletronorte ${ }^{33}$.

A morosidade e sucessiva suspensão do processo demarcatório revelou para os Krĩkati o jogo de "faz de conta" do Estado, por ele acionado em diversos contextos quando se trata do cumprimento dos direitos indígenas ${ }^{34}$. Até aquele momento em que foram impedidos de voltar para a aldeia, os Krîkati haviam agido sobre o processo produzindo documentos para afetar seu ritmo e percurso, principalmente com a produção de abaixo-assinados ${ }^{35}$. Entretanto, essa estratégia de agir por meio de abaixo-assinados enviados às diversas instâncias dos Poderes Legislativo e Judiciário, denunciando a situação de tensão na área e solicitando a resolução do caso, pareceu produzir pouca coisa além de novos documentos e papéis. 0 Estado continuava com seu jogo de fazer de conta que suas leis e normas estavam sendo cumpridas e que não eram vidas que estavam sob risco. Quando os Krĩkati abandonaram a guerra de papéis para agir na terra, suas ações ganharam potência e transformaram a dinâmica do processo.
Derrubar as torres de transmissão foi uma estratégia de grande impacto, bem como uma forma de dar visibilidade midiática ao conflito. Na edição do dia 13 de fevereiro de 1997 do jornal 0 Imparcial, o cacique da aldeia João Piauí afırmou que eles não permitiriam ninguém entrar na área para consertar as torres e que, tampouco, aceitariam qualquer redução de limite. Afırmava, assim, que “(...) não tem acordo. 0 tamanho da reserva tem que ser este [146.000 ha]". 0 conserto das torres da Eletronorte ficava, então, condicionado à demarcação de suas terras. A máquina judicial teria, mais uma vez, de conviver com “a justiça feita pelas próprias mãos" (COELHO, 2002, p. 274).

A ação dos Krĩkati de derrubada das torres fez a demarcação acontecer e possibilitou a entrada de novos atores no processo de demarcação, a partir da formação de uma Comissão Interministerial encarregada de garantir o acesso dos técnicos da Eletronorte ao patrimônio comprometido pela ação dos índios (CORRÊA, 2000). Note-se que o objetivo central não era o de solucionar o problema dos índios, mas sim o de solucionar o problema das torres que estavam causando prejuízos diários, que chegavam à faixa de 150 mil dólares para o consórcio de alumínio do Maranhão, Alumar (CORRÊA, 2000, p. 157). A Comissão

32. Esse grupo era formado por jovens Krĩkati na casa dos 20 anos, que resolveram tomar a frente do processo de demarcação. Assumiam a função de cacique; outro de chefe de posto; presidente de associação etc. Pediram permissão aos mais velhos da aldeia São José para tomar a frente do processo de demarcação, após acompanharem a luta dos mais velhos em demarcar a terra e não ver seus resultados. Seu Francisco Milhomen, o primeiro cacique da aldeia São José, ao se referir às muitas vezes que foi para Brasília buscar resolver a demarcação da terra dizia: "meu rastro tá fundo para Brasília, igual tatu".

33. Depoimento dado por Lourenço, aldeia Jerusalém, 29.09.2014.

34. Cf. Molina (2017) para outros casos nos quais o Estado atua por "faz de conta", e assim impede o cumprimento dos direitos indígenas, principalmente o direito à terra tradicionalmente ocupada.

35. Cf. Corrêa, 2000. 
Interministerial formulou com os índios uma estratégia para realizar a demarcação física da área. A TI foi dividida em seis módulos que seriam demarcados simultaneamente ao pagamento das indenizações das benfeitorias de boa-fé3 ${ }^{36}$. Os Krĩkati se encarregariam de abrir as picadas e colocar as placas para a demarcação.

0 prazo para a demarcação física da Terra Indígena determinado em juízo foi de trinta dias, segundo relatou Lourenço ${ }^{37}$. A pressão para a rápida finalização da ação foi reforçada pela Eletronorte e pelo governo do Estado, que queriam que a transmissão de energia fosse reestabelecida com urgência.

As lideranças Krĩkati - hoje anciões Benjamin, Renato e João Grande contaram que, no afã de terminar a demarcação física no prazo, áreas importantes do território identificadas pela perícia de Ladeira ficaram de fora do traçado territorial. Os dois primeiros citam a aldeia Bacuri Seco, onde o avô do primeiro cresceu e a mãe do segundo nasceu, como um desses lugares. Essa aldeia ficava na região do Arraia, segundo Benjamin, a mais prejudicada no processo de demarcação física:

Para o lado do Arraia não ficou certo; lá onde mamãe nasceu, tinha uma aldeia que ficou para fora, aldeia Bacuri Seco; e esse ponto aqui, esse lado; lado do raiz para cá [aponta no chão-traça, os limites da terra] para cada curva ficou um pedaço para fora; e tinha uma pessoa, índios mesmo se zangou porque não pegaram reto [linha seca]; ele queria que fizesse linha seca pra isso [mostra no chão como ficou no Raiz]; lá para o lado do Arraia, onde mamãe nasceu, aldeia tá bem aqui [mostra no desenho] e Arraia tá bem aqui. Ficou esse lado aqui para fora, aldeia se chama aqui Bacuri Seco; lá que mamãe nasceu, terminou de se criar e ficou uma mocinha e passou para cá [aldeia São José] (Benjamin, aldeia São José, 23 jul. 2014).

Todos os indivíduos mais velhos da aldeia São José, com os quais tivemos a oportunidade de conversar, afirmaram que foi devido à pressão em realizar a demarcação física em um prazo muito curto que partes do território identificado como de ocupação tradicional ficaram de fora do traçado final. Zé Torino Krĩkati relatou o ultimato dado para encerrar o processo pela equipe da Polícia Federal que os acompanhava na demarcação: alegaram terem outras atividades, portanto, precisavam ir embora em curto prazo. Ao comentar sobre a pressão da Polícia Federal, Zé Torino reforça o argumento de Benjamim, como podemos ler a seguir:

Parte da área que ficou do lado de fora [foi] subindo o Arraia: Faveira e por lado do Coroatá [ou Croatá]; Polícia Federal já tava como diz, 'vou embora amanhã, amanhã equipe da Polícia Federal vai sair’; então querem que nós faça mesmo que for torto, torto, mas nós temos que topar para nós sair; então foi nisso que saiu torto (Zé Torino, aldeia São José, 26 jun. 2104.).

36. Segundo Ladeira (ISA/1996-2000) a proposta de demarcação acordada garantia a demarcação dos limites em um módulo e sua simultânea desintrusão, com o pagamento das indenizações dos ocupantes não -índios na terra. Entretanto, faltaram recursos para a efetivação da proposta na íntegra. A falta de recursos para a desintrusão dos módulos pelos órgãos competentes, não impediu que os Krĩkati dessem continuidade ao processo de demarcação de todos os seis módulos.

37. Informação obtida em conversa com Lourenço Krĩkati na aldeia Jerusalém em 28 de setembro de 2014. 
Se a pressa impediu que a demarcação ocorresse nos moldes do limite levantado na perícia de Ladeira (1989), a falta de recursos dos órgãos competentes e a contínua entrada de apelações judiciais movidas pelos fazendeiros, questionando o tamanho da terra demarcada para os Krîkati, impediram a finalização do processo de desintrusão da TI em alguns dos módulos. Um desses módulos, é justamente o da região do Arraia ${ }^{38}$. Se houve pressa para finalizar a demarcação física e, desse modo, restaurar o funcionamento das torres de transmissão da Eletronorte, o mesmo não se pode dizer sobre garantir a integridade dos direitos indígenas pois, até os dias de hoje, os Krĩkati aguardam a desintrusão da área, enquanto o Estado faz de conta que os direitos indígenas estão garantidos.

Quase trinta anos se passaram de idas e vindas de papéis nos interiores da burocracia do Estado desde o início do processo de retirada dos invasores não índios da TI Krĩkati, e o processo permanece inconcluso (e a vida na terra, incerta). A primeira proposta de retirada e indenização dos ocupantes não índios foi elaborada no parecer expedido pelo juiz federal em $1991^{39}$. 0 modo do Estado agir frente aos direitos indígenas fica evidente: uma infınidade de normas e burocracias são criadas e cumpridas, produzindo um sem fim de papéis que produzem mais papéis, mas que pouco agem sobre a terra e sobre a consolidação dos direitos indígenas. As pressões políticas e as ações judiciais dos fazendeiros amplificam a produção de papéis e produzem mais morosidade dentro do Estado, ao paralisar as ações administrativas da Funai e impedir a conclusão do processo de regularização da TI Krĩkati. 0 tempo para concluir a desintrusão já é quase o mesmo que o tempo para concluir o processo de identificação, demarcação e homologação da Terra Indígena. A morosidade do Estado age impedindo que os direitos indígenas sejam cumpridos de fato.

Os Krîkati acompanham os anos passarem enquanto poucas ações são efetivadas na terra, e apenas os papéis se movimentam entre as mesas e pastas da burocracia Estatal. Foi assim que, em 2013, o MPF recomendou à Funai que concluísse o processo de regularização fundiária da Terra Indígena no prazo máximo de um ano, com a completa retirada dos ocupantes não índios da terra e determinou ao Incra a prioridade ao respectivo reassentamento desses ocupantes ${ }^{40}$. A Funai, então, notificou os ocupantes não índios da TI Krîkati determinando que deviam desocupar a TI no prazo de trinta dias ${ }^{41}$. Notificados que seriam retirados da terra, os fazendeiros entraram na justiça e solicitaram a suspensão do referido edital da Funai ${ }^{42}$. A juíza respon-

38. 0 Arraia é módulo ocupado por fazendeiros com maior poder aquisitivo comparado com os demais que ocupavam a TI.

39. Seguido do parecer do juiz, a Funai solicitou ao Ministério da Justiça que fosse feito o levantamento fundiário da terra. Em novembro de 1991 a Funai iniciou o levantamento fundiário e ocupacional da terra. Entretanto, os ocupantes não-índios da terra não forneceram as informações necessárias e dificultaram o acesso às ocupações (FUNAI, 1991)

40. Procedimento $\mathrm{n}^{\circ} 1.19 .001 .000058 / 2013-49$

41. Edital de $n^{\circ} 1 /$ DPT de maio de 2014.

42. Alegaram a posse de títulos de propriedade da terra e apontaram discrepância entre o tamanho da área declarada na sentença de 1991 de limites de 85.000 ha e aquela de fato demarcada administrativamente, de 144.675 há. Entretanto, eles cometeram um equívoco porque a área mencionada na sentença foi a levantada pelo laudo pericial antropológico solicitado pelo juiz responsável pela ação judicial e era de 146.000 ha. 
sável pela decisão proferiu sentença favorável aos fazendeiros tendo como base o fato de a decisão do juiz (em 1992) ter sido deferida sem julgamento de mérito pelo tribunal. Com base nessa leitura, proibiu a Funai e a União de retirar os ocupantes não índios da terra ${ }^{43}$.

Os Krĩkati, como forma de protestar contra a decisão da juíza, elaboraram uma "Carta Aberta" aos órgãos competentes solicitando a imediata revogação da liminar ${ }^{44}$. Em agosto de 2014, o juiz federal afirmou não ver divergências no traçado da área, como alegado pelos autores, e revogou a decisão da juíza que suspendia a retirada dos ocupantes não índios da TI Krĩkati. Ao mesmo tempo, fixou o prazo a ser cumprido pela Funai para a retirada dos invasores até 31 de dezembro de 2014. 0 juiz chamou ainda atenção para a morosidade no processo de regularização fundiária da terra, uma vez que essa ação judicial movida pelos fazendeiros contra a demarcação da TI Krĩkati já "está perfazendo a quarta década, somando mais de 34 anos de existência, tendo sido inusitadamente objeto de três sentenças anuladas em grau de apelação" 45 .

As constantes investidas e derrotas dos órgãos públicos em demarcar a terra, a pressão política e constantes apelações judiciais movidas pelos fazendeiros para re- tardar a desintrusão da TI ameaçam a vida e a terra dos índios. É o que veio nos lembrar o atentado aos Krĩkati Daniel e Otávio na região do rio Arraia. Os índios novamente se veem frente a uma encruzilhada na qual a guerra de papéis parece produzir apenas mais papéis, mas pouco fazer para assegurar seus direitos. Enquanto isso, os conflitos na terra se acirram.

A análise de Coelho (2002) sobre a morosidade e contradições presentes na ação dos órgãos públicos no caso da disputa pela terra - entre moradores não índios de povoados dentro da TI Cana Brava/ Guajajara e índios Tentehar/Guajajara ${ }^{46}$ -, revela um jogo político que se aproxima em muito do jogo político que vemos se desenvolver na luta dos Krĩkati pela desintrusão de sua terra. Segundo Coelho, esse jogo político tem como regra básica a incapacidade do Estado brasileiro em reconhecer os povos indígenas como povos específicos e respeitar seu direito à posse de um território exclusivo. Essa dificuldade gera o conflito entre o "Estado conquistador" e o "Estado protetor" e revela que por trás e acima do ordenamento jurídico está o poder político que, ao fim e ao cabo, define as regras da disputa pela terra no país (COELHO, 2002).

43. Ação Demarcatória de $n^{\circ}$ 00.00.05521-2. Imperatriz/Ma. jun.2014.

44. 0 argumento principal da carta era de que os títulos de propriedade dos fazendeiros já haviam sido julgados nulos em ação judicial anterior. Alertaram ainda para a insegurança física e cultural a que ficaram expostos com a decisão da juíza visto a coexistência deles com moradores não-índios dentro de sua terra.

45. Ação Demarcatória de nº 00.00.05521-2. Imperatriz/Ma. jun.2014.

46. Essa dinâmica de disputa pela terra foi analisada no contexto da luta dos indios Tentehar/Guajajara de retirar de dentro de sua terra demarcada, a TI Cana Brava/Guajajara, dois grandes povoados: Alto Alegre e São Pedro dos Cacetes. 


\section{Os efeitos da demarcação sobre o modo de habitar Krĩkati: o "espalhar" e o "ajun-

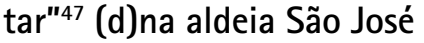

Os Krĩkati permaneceram juntos na aldeia São José por trinta anos. Antes disso, entretanto, resistiram a se "ajuntar" em uma só aldeia devido à sua territorialidade própria, seus modos de construção de lugares e socialidades. Fixar moradia na aldeia São José implicava alterar a dinâmica de, em suas próprias palavras, “ajuntar” e "espalhar”. Os Krĩkati descrevem dois acontecimentos como tendo-os induzido a fixar residência nessa aldeia: o acordo feito entre eles e fazendeiros e intermediado pelo prefeito de Montes Altos e a construção da primeira escola para índios na São José pelo frei Aristides. Ambos os acontecimentos se deram quando os Krĩkati estavam espalhados por quatro aldeias: São José, Baixa Funda, Bateia e Cabeceira das Cabras.

Assim como os demais povos Timbira, os Krîkati sempre se “ajuntavam” nos momentos das grandes festas rituais (amjôhquehn, na língua krĩkati), onde se reuniam parentes e convidados em uma só aldeia, às vezes por meses. Entretanto, quando a festa encerrava eles se dispersavam novamente, como narrou Urbano:

Quando fazia brincadeira se ajuntava tudo; quando termina brincadeira a gente se espalha; São Gregório era aldeia nova; agora Bateia era aldeia velha, era onde eu morava; agora mudaram lá para São Gregório; su- biram para cá e se ajuntou de novo; é quase como o branco quando faz festa; se ajunta e quando termina, se espalha; quando tinha brincadeira na Bateia a gente vai para lá, brinca, e quando termina vai embora; aqui na São José vem tudo para cá; tinha brincadeira na Baixa Funda vai para lá; aí acaba a gente espalha de novo (Urbano, aldeia São José, 4 jul. 2014).

A antropóloga Jean Lave, que estudou os Krĩkati nos anos 60 e 70, descreve que, com exceção das épocas cerimoniais, os grupos domésticos eram autônomos e interagiam pouco, como podemos ler em suas palavras (1967, p. 28):

Um dos aspectos básicos da vida diária dos Krĩkati é que os grupos domésticos são independentes, uns em relação aos outros. Ficam muito tempo fora da aldeia [acredito que em áreas de roça] e interagem pouco entre si, exceto, nas atividades rituais e nas interações formais entre afıns. Cada grupo doméstico carrega consigo o padrão cerimonial e ritual Krîkati como um todo. Entretanto, para a realização de cerimônias precisam de mais de um grupo doméstico.

A junção de todos os Krĩkati na aldeia São José não foi um processo rápido. Fruto da intervenção do prefeito de Montes Altos e do frei Aristides, a concentração em uma única aldeia liberou o território krĩkati para os fazendeiros, ao mesmo tempo que foi também uma estratégia de segurança dos indios contra eventuais ataques dos fazen-

47. "Espalhar" (ajcrỳ) e “ajuntar” (cohprõ) são categorias êmicas que explicam a dinâmica Krĩkati de deslocamento pelo território. Esse mesmo deslocamento, antropólogos como Lave (1967) e Azanha (1984) chamaram de fusão e cisão. 
deiros $^{48}$. Dona Tereza, cujos parentes moravam na aldeia Bateia, a última a se juntar na São José, afirmou que era muito perigoso morar afastado dos demais "porque o povo ajuntou aqui na São José; [então] não pode ficar morando sozinho não" (Tereza, aldeia São José, 7 abr. 2015). Se "ajuntar" em uma só aldeia era uma forma de se proteger do perigo gerado pela proximidade com os não índios e pela ausência de uma Terra Indígena demarcada que seria, a princípio, protegida pelo Estado.

A concentração gradativa na aldeia São José pode ser percebida como uma convergência contingente de trajetórias dos diversos grupos Krĩkati que habitavam lugares distintos de seu território. Tal concentração é um momento particular da forma de organização territorial Krĩkati, que se baseia na alternância de movimentos de "espalhar" e se "ajuntar" em grupos locais cindidos de seu grupo doméstico. Essa dinâmica é o modo Krĩkati (e Timbira, no geral ${ }^{49}$ ) de viver, no qual se busca sempre estar "entre si”. Ao realizar trabalho de campo entre esse povo, pudemos escutar as mulheres dizerem: "pode sentar, aqui só estamos entre a família mesmo, todas essas casas aqui são parente"; ou ao perguntar o porquê de terem formado uma nova aldeia: "porque lá na aldeia grande [São José] não estava bom, tinha muita gente e bom é ficar só a gente mesmo". Ou ainda na forma de um desejo não realizado, mas sempre presente: "nós vamos formar uma aldeia ali no $\mathrm{Ca}$ boclo Velho, vamos voltar lá na área que meus avós moravam para poder ficar só a nossa família mesmo". Ficar "entre si”, no entanto, é sempre um objetivo inalcançável para povos que se constituem criando diferenças internas que os levam a estar continuamente constituindo novas aldeias, expandindo-se pela terra e multiplicando a “forma timbira”, como denominou Azanha (1984, p. 16), em constante reterritorialização e reconstrução de lugares habitados.

Essa situação contingente de estar em uma única e grande aldeia foi se tornando permanente entre os Krîkati na medida em que houve um aumento contínuo do número de invasores nas suas terras. Ameaçados e acuados os indígenas foram obrigados a diminuir o movimento pelo seu território que, simultaneamente, foi se tornando, da perspectiva da ocupação física do povo, cada vez menor. Durval Krĩkati descreve que antes da regularização fundiária o território deles estava tão invadido pelos não índios, que ele se sentia

vivendo no meio dos brancos" que, para além de invadirem suas terras, ainda afirmavam "que eles [não indígenas] estavam criando índio. Mas é mentira [diz ele]; não davam sustento para nós ${ }^{50}$ (Durval, aldeia São José, 26 jun. 2014).

48. Lave (1967, p.16-17) quando esteve junto aos Krĩkati em 1963/64 encontrou duas aldeias: São José, com 150 pessoas; e São Gregório com 57 pessoas. Delvair Melatti (1980, p.20-21), que lá esteve em 1979, cita a existência de quatro aldeias: São José, Bateia, Dalgado e Areia (esta última do povo Tentehar-Guajajara). Na São José havia 256 pessoas; Bateia, 11 pessoas; Dalgado, 8 pessoas; e Areia, 21 pessoas. Na estadia de Melatti já se percebe uma maior concentração de Krĩkati na aldeia São José.

49. Poderia dizer também ameríndio, uma vez que este se apresenta como o ideal almejado em diversas narrativas e mitos dos povos das terras baixas da América (cf.Levi-Strauss, 2004).

50. Essa fala de Seu Durval parece refletir o fato de que um dos termos do acordo entre brancos e índios (citado acima) ter sido a doação de gado aos últimos. 
Retomemos o argumento de Ladeira de que a demarcação de uma Terra Indígena se faz necessária devido à "pressão que a sociedade nacional faz sobre esses territórios para ocupá-los 'produtivamente" (1989, p. 7) e que o que este ato garante, portanto, é o cumprimento do direito indígena à terra. Para cumprir devidamente com o texto constitucional, o processo de regularização fundiária de uma TI deve identificar o "território tradicionalmente ocupado" pelos índios com o objetivo de demarcar uma terra que não ignore os lugares do passado que são atualizados no presente (seja por meio de memórias ou de trajetórias percorridas) e também permita ao povo concernido um futuro. Se assim o fizer, ainda que o modelo de demarcação seja uma imposição do Estado de seu modo de ordenar e dominar a terra, os limites da TI não bloquearão o crescimento e coexistência das $\mathrm{T} /$ terras vividas pelo grupo, e possibilitarão a manutenção das vidas de seus diferentes habitantes (não obrigando os indígenas a se transformar em trabalhadores rurais).

A demarcação física da Terra Indígena deveria, portanto, garantir aos Krîkati a retomada da alternância de movimentos de "espalhar" e "ajuntar" que marcam a sua forma de ocupar o território. Foi exatamente o que ocorreu alguns anos após a homologação da demarcação e da, ainda inconclusa, desintrusão da TI. Lideranças Krĩkati elaboraram um plano de gestão e monitoramento da terra com vistas a criar aldeias em linhas limítrofes ao traçado da terra demarcada para evitar invasões:

0 plano de gestão e monitoramento começamos a pensar logo depois da demarcação; não é de fiscalização; é de monitoramento; é você caçando, pescando, olhando terra; fazendo monitoramento; a presença dos indígenas dentro do território evita impacto, agressão e exploração [ao meio ambiente]; nós fizemos plano de monitoramento já pensando nisso já (...); ponto estratégico é ocupar o território (Lourenço Krĩkati, aldeia Jerusalém, 28 set. 2014).

A primeira aldeia a ser construída foi a Raiz, pelo então cacique da aldeia São José, João Piauí. A escolha do lugar para se levantar a aldeia se deu no momento em que ele passou por lá, à época em que abriram as picadas e colocaram os marcos para a demarcação da terra. Contou Raimundinho Krĩkati que “João Piauí gostou do local da aldeia Raiz, (...) ele já avisou a todos que aquele lugar onde tinha aquela água ia ser dele" (Raimundinho, aldeia São José, 26 jun. 2014). A água parece ter sido um elemento definidor na escolha da aldeia Raiz, em contraste com a aldeia São José, que não tem áreas de águas naturais

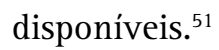

Depois da Raiz, foram construídas também as aldeias Recanto do Cocais ${ }^{52}$, Cam-

51. Águas de recursos naturais estão bem distantes da aldeia São José e, até a demarcação acontecer, todas estavam ocupadas pelos não-índios e seus rebanhos de gado.

52. Uma nova aldeia foi construída somente para os índios Tentehar/Guajajara que à época da demarcação estavam espalhados na aldeia São José por conta dos conflitos com fazendeiros. Havia apenas a família de Manoel Mendes, que havia sido assassinado em episódio já relatado. Devido ao envolvimento dele na luta pela demarcação da TI Krîkati e em sua memória, os Krìkati dizem ter pensado em fazer essa aldeia para morar somente o povo Tentehar/Guajajara. 
po Alegre, Jerusalém e Arraia. Entretanto, a iminência de criação de novas aldeias está sempre presente nas conversas com os Krĩkati. À medida que os invasores vão saindo da terra e a mata vai crescendo, aumentam as possibilidades para eles reproduzirem a forma tradicional de ocupação de seu território. Um exemplo é a possibilidade posta por Jair Krĩkati de fundar uma aldeia na região do riacho Batalha ${ }^{53}$, mais precisamente na região do Baixão, onde já ocupa como lugar de roça. A escolha desse lugar não está ligada somente à roça, mas ao fato de ele ter morado com seus avós e pais nesse lugar. Jair tem na memória a história do processo de conquista do lugar pelo avô Agostinho ${ }^{54}$. Também têm memórias relativas às suas andanças com os pais e os irmãos quando criança:

Eu vi os meus pais e meus avôs; passaram e conquistaram esse lugar onde só eles que chegam lá e com outros parentes da aldeia, eles andam juntos, andam em grupo mesmo; e aonde que acompanhei quando era criança; aonde veio outras estórias de meu avô Agostinho, na língua, Promtac, aonde foi ele que tomou esse espaço ali e gostou de andar para lá com meu pai, com meu irmão mais velho, no espaço que chamam Baixão, espaço que tem descida e subida; então ele tomou esse conhecimento para lá e com tudo isso, eu vendo estória, andada, e acompanhei desde criança; cresci andando para lá; ficar para lá ou passar uns tempos para lá; aí estou começando lá, gostei do lugar (Jair, aldeia São José, 3 out. 2014).

A ligação que ele estabelece com o lugar de "origem" de seus ancestrais e o fato de esse mesmo lugar ser "bom para plantar", terra boa ( pji ẽhmpex), são elementos que sustentam o desejo de construir uma aldeia nesse lugar. Apesar de ainda ser uma área invadida por não indígenas, ele afirma que consegue ficar ali sem entrar em conflitos. Entretanto, a situação da área é de insegurança, pois apesar de ausente no presente, o conflito permanece ali como ameaça à vida naquela terra.

A relação entre lugar, trajetória e memória presente na proposta de criação da aldeia Batalha também aparece na, já formada, aldeia Arraia. Fundada no ano de 2013, concentrou três elementos eleitos como importantes para a fundação de uma aldeia: a água - o local concentra um dos maiores recursos hídricos da terra; a relação com antepassados -, o lugar abrigou antigas aldeias; e estar dentro da área considerada prioritária no plano de monitoramento da terra. Esses três elementos contribuem para a permanência desse povo na região do Arraia até hoje, mesmo com não indígenas morando muito próximos da aldeia: o que separa as casas dos Krĩkati das casas dos não indígenas é uma estrada vicinal.

Sobre a relação afetiva com o lugar, o antigo vice cacique da Arraia, Artur Krĩka-

53. Em carta escrita por Dolores Newton, já citada anteriormente nesse texto, Francisco Milhomen descreve a região Riacho Batalha como um lugar de arranchamento para pescaria e como lugar que os Krĩkati queriam ver assegurados pela demarcação.

54. Agostinho, à época da dispersão da Taboquinha, fundou a aldeia Baixa Funda. Ele foi, posteriormente, eleito o juiz do acordo feito pelo prefeito de Montes Altos entre fazendeiros e Krĩkati que resultou na reunião de todo o povo na aldeia São José. 
ti, contou que a mãe ${ }^{55}$ nasceu nessa região e por isso ela retornou para lá, apesar de a área ainda estar invadida. Ele também falou sobre importância política de ocupar o lugar: "Eu quero que a Funai se preocupe com nós aqui; nós aqui estamos meio imprensados [pelos não índios], mas nós não vamos sair daqui; aqui é nosso lugar”. Permanecer na Arraia também é uma estratégia política que funciona para marcar para os moradores não índios que eles são os donos da região e que vão ficar "fixados" lá: "Se eu for sair daqui correndo com a minha tia e minha mãe e voltar [para a aldeia São José], logicamente que eu vou estar dando força para os posseiros porque eu vou estar me enfraquecendo" o que poderia, segundo ele, levar os moradores não índios a pensar: “eles já estão voltando para a aldeia e se a gente fizer esse movimento com certeza eles saem daqui. Pode parecer que eu estou querendo me bater cara a cara, mas não é. A nossa intenção é ocupar o espaço" (Artur Krĩkati, aldeia Arraia, 8 jul. 2014).

Filomena Krîkati (tia de Artur) rememora a história do lugar como a sua história e dos parentes que lá viveram com ela. Ela se autodeclara "original" desse lugar porque foi criada nele. Foram as memórias das situações que vivenciou que fizeram com que ela voltasse ao "lugar de origem" e trouxesse consigo os seus parentes consanguíneos:

Foi eu quem primeiro quis vir para cá; tem outro irmão que se chama Zé de Nazaré, mas nenhum homem se interessou para vir morar aqui para me acompanhar não; na hora que eu falo eu digo 'eu sou homem', eu venho puxando vocês que vocês 'são mulher'; eu venho puxando vocês, eu estou morando aqui mais vocês; eu coloquei: se vocês ficarem lá do outro lado, vocês não vê eu, porque é lá na Alegria que eu quero fazer minha aldeia, mas como o povo [invasor] não saiu todo, meu sobrinho trouxe nós mais a mãe dele, Maria Lucia, e colocou aqui e voltou de novo para a aldeia grande; aí veio João Grande também, passou um tempo e voltou de novo Zé Rafael também, mas voltou de novo; aí quem ficou mais eu, foi Zé de Nazaré (...) (Filomena, aldeia Arraia, 8 jul. 2014).

Ela rememora quando teve de sair da região do Arraia para ir morar na São José. A mudança teria ocorrido, segundo ela, quando um de seus avós foi buscá-los no Arraia porque estavam sozinhos e todo o povo já se concentrava na São José. Entretanto, quando seus avós morreram e a aldeia São José cresceu muito, não "tendo mais areia para sentar", mas somente barro duro, ela sentiu necessidade de voltar para seu "lugar de origem”, como podemos ler a seguir:

Eu estou morando aqui que meu avô que andava comigo, fica do outro lado, lá no Alegria, é lá que quero para fazer uma aldeia para nós irmos morar; aí outro meu avô, veio aonde nós e aí conversou com meu avô, conversou muito; disse que nós estávamos sozinho aí; depois que meu avô, que se chama Artur, chegou, conversou com Zebinho, tudo, aí levou nós de volta para lá, para aldeia grande [São José]; aí nós ficamos morando

55. A mãe de Artur é Maria Lucia que faleceu em 2016 de problemas renais. Até o ano de 2015, quando não estava hospitalizada em Imperatriz, ficava na aldeia Arraia, mesmo contra a orientação médica que a encaminhava na alta para a aldeia São José devido à estrutura de saúde mais adequada (posto de saúde, enfermeiros e médicos) para recebê-la do que o Arraia. 
na aldeia grande; aí morreu; desde que morreu eu venho lutando para mudar para cá; aí com isso que meu avô morreu, aí eu falei: - um dia desses que nós estávamos sentada mais Maria Lúcia, se você quiser ficar aqui pode ficar; aí mora aqui no meio do povo; agora eu, que acabei de me criar lá no Arraia, pois eu vou morar lá; aonde que meu bisavô nasceu, se acabou de criar, pois eu vou morar lá; ele gostava de andar comigo para lá desde quando eu era pequena; ele anda comigo; pois acabei de me criar foi por lá; pois eu vou morar lá com meu neto; meu neto já está tudo grande; aí eu vou morar lá; meu neto que fez uma aldeinha para nós morar lá; aí com isso que Maria Lúcia falou para mim dizendo: - é, só se for, tu não tem nem teu irmão, tu pode morar só; eu também vou sair; só nós duas que vamos sair para ir lá para o Arraia (Filomena, aldeia Arraia, 8 jul. 2014).

Os seus parentes da aldeia São José dizem a ela que não deveria permanecer na região porque haveria poucos homens com ela, e ela estaria muito perto dos moradores não indígenas. Entretanto, ela diz não ter medo e afirma que a região do Arraia é o único lugar onde ela consegue plantar, criar e sobreviver de sua plantação e criação, em suas palavras:

Na demarcação, eu não sou como os outros; aí saíram correndo, correndo, entraram no mato e a pessoa foi atrás de mim, trouxeram eu de lá do mato na aldeia de volta de novo; eu não fui assim; segurei minha casa lá [na região do Arraia] até quando terminou tudo; pois igual eu fico aqui; se tem deles que endoida e aí se quiser me matar, me mata (...); porque aqui é minha aldeia [Arraia], minha aldeia; eu tenho que segurar mesmo aqui; e como que eu vou correr? (...); só vou para a aldeia grande quando é para uma visita, quando acaba a visita eu volto de novo para o Arraia porque aqui é minha aldeia; minha aldeia; se eu quiser morrer, eu morro e vão me enterrar junto aqui com meu bisavô; isso é o que eu quero; eu não quero mais ficar na aldeia grande não; quando eu vou para lá sempre adoeço; olha aí não está vendo, eu estava aqui boazinha, boazinha e aí fui para lá, senti um frio em meu corpo e parece que fiquei com febre; fiquei tremendo; ai eu fiquei tremendo e dormi na beira do fogo ( $\mathrm{Fi}-$ lomena, aldeia Arraia, 8 jul. 2014).

Na narrativa de Filomena, fica explícita a relação vital com o lugar. Não há vida possível fora dali, visto que ao sair sua vida está em perigo: ela adoece. Por isso, o risco de viver ali não aparece para ela do mesmo modo como para seus parentes da aldeia grande de São José. 0 risco de estar fora dali é igualmente grande (ou maior). Contudo, antes da demarcação, Filomena estava vivendo na São José, assim como João Piauí, e foi o próprio processo de demarcação que engendrou novas relações com os lugares. Ao caminhar pela terra para abrir as picadas, Piauí encontrou o lugar onde queria viver e lá decidiu abrir a aldeia Raiz. Seguindo a trilha de Molina (2017) e Souza Coelho (2013), é possível dizer que a demarcação reanimou certos lugares, trouxe -os "de volta à vida". A aldeia do Arraia pôde voltar à vida após a demarcação e, talvez, o que Filomena esteja afirmando quando diz que não sairá e lá poderá morrer, seja que ela mesma pôde voltar à vida somente no Arraia.

Se por um lado a demarcação garantiu uma terra para os Krîkati, por outro ao não retirar os não índios do Arraia, ela não efetivou a garantia desse direito para todos os do povo, como nos mostrou Filomena e sua família, que continuam com suas vi- 
das e sua terra sob ameaça. A relação com os ocupantes não índios da região, por sua vez, não é vivida todo o tempo como conflito, como contou Artur: "Nós somos amigos, mas não amigo de chegar toda hora e conversar; a gente não tem nada um contra o outro; a gente não mexe nas coisas deles e eles não mexem conosco; a gente conversa normalmente com eles, mas nós não falamos dos problemas”. Ao conversar sobre a desintrusão da terra com os não índios, afirmou que alguns dizem que os Krîkati "não têm nada a ver [com a situação deles com o governo]; foi o governo que errou com a gente" (Artur Krĩkati, aldeia Arraia, 8 jul. 2014). Entretanto, Arthur não deixou de alertar em sua fala para a urgência de os não índios desocuparem a região, pois a permanência deles ali impede que os Krĩkati andem com liberdade: podem se deslocar somente pelo riacho, pescar e retornar logo para as suas casas.

\section{Considerações finais}

A luta dos Krĩkati por assegurar o direito de viver na terra por eles tradicionalmente ocupada, constituída, como pudemos ler nas narrativas acima, a partir dos movimentos de "espalhar" e se "ajuntar" que caracteriza seu modo de ocupar a T/terra (criando lugares: habitats constituídos por hábitos), foi formalizada nos documentos do Estado em 1974 quando a primeira proposta de limite da área krĩkati foi elaborada. Entretanto, vemos que o direito indígena de viver na terra reconhecida como de ocupação tradicional, apesar de afirmado pela demarcação e homologação da Terra Indígena, permanece ameaçado em virtude da ainda intrusão de partes do território por não índios.

Embora os Krĩkati detenham a posse permanente da terra, garantida pela ho- mologação, a existência da TI permanece sendo continuamente questionada por ações judiciais dos não índios. 0 fato dessas ações conseguirem agir tanto no nível dos papéis como da terra, impedindo o usufruto indígena da mesma, aponta para o fato de que os direitos territoriais dos índios são vítimas de jogos burocráticos e jurídicos de "faz de conta", que resultam na produção de papéis, mas não na consolidação de direitos. Como pudemos acompanhar, os argumentos elencados pelos não índios para permanecerem na terra kríkati são os mesmos desde 1981: os seus títulos de propriedade, os quais já foram declarados nulos. Com base na tese de que são proprietários de partes da terra demarcada, os fazendeiros recorrem à justiça toda vez que os órgãos competentes se organizam para retirá -los da área da Terra Indígena. Ainda que os títulos já tenham sido anulados, a máquina do Estado opera da mesma maneira, analisando novamente os mesmos velhos papéis e criando novamente as mesmas burocracias que produzem a morosidade do Estado. Dessa maneira, os fazendeiros conseguem manter o processo inconcluso até os dias atuais, enquanto o Estado "faz de conta" que os direitos Krĩkati de usufruir a terra, segundo seus usos, costumes e tradições estão sendo garantidos.

A morosidade do Estado paralisa papéis, mas não é capaz de paralisar a vida na terra que segue em situação de conflito iminente entre índios e não índios, principalmente nas áreas da TI onde os invasores permanecem. Em maio de 2017, o atentado contra os índios que estavam pescando em um açude nas proximidades do rio Arraia revela a urgência da vida, frente à lentidão da máquina do Estado. Os Krĩkati sabem que vivem na região do Arraia em uma situação de insegurança, quem faz de conta 
que desconhece essa situação são os órgãos do Estado, responsáveis pela desintrusão da área e pela garantia da vivência e da sobrevivência dos Krĩkati.

Se no caso explorado por Molina (2017, p. 144) "o modo de enunciação mobilizado pelos Munduruku em suas cartas [da autodemarcação, produzidas ao longo do processo e publicadas em seu blog] permite que se traiam as regras de um jogo que torna possível, para o governo federal, fazer de conta que uma determinada TI e sua população não existam”, no caso que acompanhamos aqui o que se dá é uma certa torção nesse jogo. Aqui o Estado faz de conta que a TI Krĩkati está realmente homologada, ignorando que, para tanto, ela deveria ter sido desintrusada; enquanto os fazendeiros e a justiça local fazem de conta que a homologação não ocorreu, que seus títulos não foram considerados nulos, ignorando a legalidade do processo e fazendo de conta que não há ali uma Terra Indígena. Entretanto, se o Estado pode operar por faz de conta, Filomena e sua família não. 0 que podem é apenas desvelar esse jogo perverso, arriscando a vida na terra, pois é apenas ali que ela pode acontecer.

\section{Referências}

AYRES B, C. Voto do Ministro Relator. In: MIRAS et al. Makunaima grita: Terra Indígena Raposa Serra do Sol e os direitos constitucionais no Brasil. Rio de Janeiro: Beco do Azougue, 2009.

AZANHA, G. Conhecimento e sentimento entre os Jê-Timbira do Brasil Central: revisando alguns conceitos. Acervo Centro de Trabalho Indigenista, 1991.

A forma Timbira: estrutura e resistência. 1984. Dissertação (Mestrado em
Antropologia Social) - FFLCH, Universidade de São Paulo, São Paulo, 1984.

BARROS, M. M. S. Wu'tu: o processo recriador da etnicidade Krĩkati. 1999. Dissertação (Mestrado) - FFCL, Universidade Estadual “Júlio Mesquita Filho", Araraquara, 1999.

BOTELHO, J. et al. Os povos indígenas e o Projeto Ferro-Carajás: avaliação do convênio. Dez, 1985. Disponível em: <http:// bd.trabalhoindigenista.org.br/sites/default/ files/CTI01941.pdf>. Acesso em: 15 out. 2017

BRASIL. Decreto-lei no 1775, 8 de janeiro de 1996. Dispõe sobre o processo administrativo de demarcação de terras indígenas e dá outras providências. Diário Oficial da União, Brasília, 1996.

CASEY, E. S. How to get from space to place in a fairly short stretch of time: phenomenological prolegomena. In: FELD, S. \&t BASSO, K.H. (Eds.), Senses of place. 1996, p. 13-52.

CLASTRES, P. A sociedade contra o Estado. São Paulo: Cosac \& Naif, 2003.

COELHO, E. M. B. Territórios em confronto: a dinâmica da disputa pela terra entre índios e brancos no Maranhão. São Paulo: Hucitec, 2002.

COELHO DE SOUZA, M. et al. T/terras indígenas e territórios conceituais: incursões etnográficas em tempos de guerra. Projeto de pesquisa. Brasília, 2016.

COELHO DE SOUZA, M. Dois pequenos problemas com a lei: terra intangível para os Kisêdjê (Suya), 2014. No prelo.

A vida dos lugares entre os Kisedjê (Suya). 2013. No prelo. 
CORRÊA, K. N. F. Muita terra para pouco índio? 0 processo de demarcação da Terra Indígena Krĩkati. São Luís: Edições UFMA, PROIN (CS), 2000.

. Direitos territoriais indígenas e a morosidade na integralidade do processo demarcatório da Terra Indígena Krĩkati. Trabalho apresentado no ENCONTRO NORDESTINO DA REDE LATINO-AMERICANA DE ANTROPOLOGIA JURIDICA. RELAJU/ Nordeste, 2015.

AJCRỲ / COHPRÕ: dinâmicas de "espalhar" e "ajuntar" no território Krĩkati. 2016. 260f. Tese (Doutorado em Ciências Sociais) - PPGSOC, Universidade Federal do Maranhão, São Luís/Ma, 2016.

CVRD à ABA. Programação Funai executada em 1982, progr. prevista p/ 1983, assessoramento de antropólogos ABA. Maio, 1983. Disponível em: http://bd.trabalhoindigenista.org.br/sites/default/files/ CTI01932.pdf

DELEUZE, G. \&t GUATTARI, F. 0 anti-édipo: capitalismo e esquizofrenia. São Paulo: Editora 34, 1972.

DE LA CADENA, M. Política Indígena: un análisis más allá de 'la política'. In: WAN EJOURNAL. n. 4, jan./fev. 2009, p. 139-171. Disponivel em: <http://www.ram-wan.net/ documents/05_e_Journal/journal-4/jwan4. pdf.. 2009>. Acesso em: 20 nov. 2014.

INGOLD, T. Trazendo as coisas de volta à vida: emaranhados criativos num mundo de materiais. Horizontes antropológicos, 18 (37), p. 25-44, 2012.

JUSTIÇA FEDERAL DO MARANHÃO. Processo. 00.00.05521-2 (Ação Demarcatória). Imperatriz/Ma, jun. 2014.
JUSTIÇA FEDERAL DO MARANHÃO. Processo. 00.00.05521-2 (Ação Demarcatória). Imperatriz/Ma, ago. 2014.LADEIRA, M. E. A troca de nomes e a troca de cônjuges - Uma contribuição ao estudo do parentesco Timbira. 1982. Dissertação (Mestrado) - FFLCH, Universidade de São Paulo, São Paulo, 1982.

- Perícia antropológica referente à ação de demarcação que Leon Delix Milhomen e outros movem contra a Fundação Nacional do Índio. 1989, Processo $\mathbf{n}^{\circ}$ 1875/81. Mimeo.

- A não regularização da Terra Indígena Krĩkati: até quando? Povos Indígenas no Brasil. Instituto Socioambiental, 1996/2000. Disponível em: <https://books. google.com.br/books?isbn=8585994096>. Acesso em: 31.out.2017.

LANDER, E. Ciências Sociais: saberes coloniais eurocêntricos. In: . (Org). A colonialidade do saber, eurocentrismo e ciências sociais: perspectivas latino-americanas. Buenos Aires: CLACSO, 2005.

LAVE, J. C. Social Taxonomy among the Krĩkati (Jê) of central Brazil. Harvard University, December, 1967.

LEITÃO, W. M. Laudo antropológico referente à ação de demarcação que Leon Delix Milhomen e outros movem contra a FUNAI. Brasília, 1989. Mimeo.

LEVI-STRAUSS, C. 0 cru e o cozido. São Paulo: Cosac \&t Naify, 2004.

MELATTI, D. M. Relatório sobre a eleição da área Krĩkati. Brasília: Funai, 1980.

MINISTÉRIO DA JUSTIÇA. Processo 0867/92 (expedição de Portaria Declaratória). NUDOC/FUNAI/Brasília. 
MINISTÉRIO DA JUSTIÇA. Processo. 0224/

80. Interessado: Delvair Montagner Mellati. Resumo: Relatório Área Krikati. NUDOC/ FUNAI/Brasília.

MIRAS, J. T. De terra(s) indígena(s) à Terra Indígena: o caso da demarcação Krĩkati. 2015. 140f. Dissertação (Mestrado em Antropologia Social) - DAN/PPGAS, Universidade de Brasília, Brasília, 2015.

MOLINA, L. P. Terra, luta, vida: autodemarcações indígenas e afırmação da diferença. 2017. 191f. Dissertação (Mestrado em Antropologia Social) - DAN/PPGAS, Universidade de Brasília, Brasília, 2017.

NIMUENDAJÚ, C. The Eastern Timbira. University of California Publications in American Archaeology and Ethnology, v. 41, Berkeley: California Press, 1946.

NODARI, A. A( )terra(r) ("Se Gaia tem mil nomes, como você prefere chamá-la?”). Disponivel em: <http://osmilnomesdegaia. eco.br/2014/09/01/alexandre-nodari-a-terrar/2014>. Acesso em: 17 abr. 2015.

O IMPARCIAL. (São Luís), 13 fev.1997.

SCHMITT, C. The Nomos of the Earth in the International Law of the Jus Publicum Europaeum. New York: Telos Press, 2006.

SOUZA LIMA, A. C. Um grande cerco de paz: poder tutelar, indianidade e formação do Estado no Brasil. Petrópolis: Vozes, 1995. 


\section{RESUMO}

A Terra Indígena Krĩkati foi homologada no ano de 2004, contudo até hoje parte do que foi identificado e demarcado como território indígena permanece ocupado por moradores não índios. 0 presente artigo pretende refletir sobre a dinâmica krĩkati de habitar a terra a partir da demarcação (não como um marco temporal de análise, mas como um acontecimento que age na terra) e o impacto que a não desintrusão gera em suas vidas. Para tanto, apresenta o processo de regularização fundiária da TI desde seus primórdios, em 1974, até seus desdobramentos em 2014, quando aconteceu a última tentativa de retirada dos moradores não indígenas da área do rio Arraia. Ao colocar a regularização fundiária em perspectiva poderemos entender como os procedimentos de criação de uma Terra Indígena, assim como a própria categoria de TI, é algo exógeno aos povos que vivem e se relacionam de outros modos com a terra. Ao mesmo tempo, percebe-se que a vida e a T/terra estão interconectadas e que, portanto, a demarcação é fundamental para garantir o direito à vida dos povos. Contudo, ao olharmos para os percursos do processo e a morosidade do Estado em garantir o cumprimento dos direitos indígenas, vemos como tantas vezes tais direitos não se realizam.

\section{PALAVRAS-CHAVE}

Terra Indígena. Territorialidade. Vida. Estado. Demarcação. Krĩkati. Timbira.

\section{ABSTRACT}

The Indigenous land Krĩkati has been approved in the year of 2004, however part of which it has identified and demarcated as a territory so far remains occupied for residents non-Indians. The present article intends to reflect about the Krĩkati dynamics of inhabit the land stem from the demarcation (not as an analysis temporal mark, but as an event that acts in the land) and the impact that the non-intrusion results in their lives. Therefore, this work presents the process of land regularization of IL from their origins, in 1974, through their repercussions in 2014, when it happened the last try of taking the non-Indians residents away from the area of Arraia River. When placing the land regularization in perspective, we can understand how the creation procedures of an Indigenous land, as well as the proper category of a IL, is something exogenous to the people who live and relate in another way with the land. At the same time, we may infer that the life and the L/ land are interconnected, so the demarcation is fundamental to ensure the right to the people lives. However, when we look at the paths of the process and the slowness in ensure the fulfillment of the indigenous people's rights by the State, we might see as many times those rights do not take place.

\section{KEYWORDS}

Indigenous land. Territoriality. Life. State. Demarcation. Krîkati. Timbira. 
